\title{
Feasibility and Economic Analysis of Bread Production in Gashua, Yobe State, Nigeria
}

\section{Adekoyeni Oludare Olumuyiwa ${ }^{1}$ Abdulhamid Ellawule ${ }^{2}$}

'Department of Home Science and Management, Federal University Gashua, Yobe, Nigeria.

Email:oludareadek@yahoo.com

Department of Accounting, Federal University Gashua, Tobe, Nigeria.

\begin{abstract}
The feasibility and economic analysis of bread production for a modern cottage bread production business in Gashua, Yobe State was analysed. This assessment involved analysis of the project to determine the viability, cost, and benefits associated with a bakery project before financial resources are allocated. The capital investment for the bakery establishment was estimated at N10,316,303.00 with maximum capacity to utilise $10 \mathrm{bags}$ of flour $(50 \mathrm{~kg})$ per day. The production capacity is to increase at $50,60,75,85$ and 90 mi efficiency for five years respectively. The cost of production ranged between $\$ 30,776,550$ to $45,059,946.85$ while the profit after tax ranged from 12,783,071 to $18,878,298.79$ for five years. The non current asset schedule annual depreciation was estimated at \#655,000. The cash flow and breakeven point were at $\$ 1,395,161$ and 27,705 respectively. Bakery business in Gashua is worthwhile for entrepreneur as profit making venture.
\end{abstract}

Keywords: Feasibility study, Economic analysis, Bakery, Depreciation, Cash flow, Breakeven point.

Citation | Adekoyeni Oludare Olumuyiwa; Abdulhamid Ellawule (2020). Feasibility and Economic Analysis of Bread Production in Gashua, Yobe State, Nigeria. Agriculture and Food Sciences Research, 7(2): 125-130.

History:

Received: 4 May 2020

Revised: 15 June 2020

Accepted: 17 July 2020

Published: 30 July 9090

Licensed: This work is licensed under a Creative Commons

Attribution 3.0 License (cc)

Publisher: Asian Online Journal Publishing Group
Acknowledgement: Both authors contributed to the conception and design of the study.

Funding: This study received no specific financial support

Competing Interests: The authors declare that they have no conflict of interests.

Transparency: The authors confirm that the manuscript is an honest, accurate, and transparent account of the study was reported; that no vital features of the study have been omitted; and that any discrepancies from the study as planned have been explained.

Ethical: This study follows all ethical practices during writing.

\section{Contents}

1. Introduction

2. Description of Methodology and Data Collection

3. The Project

(12) 127

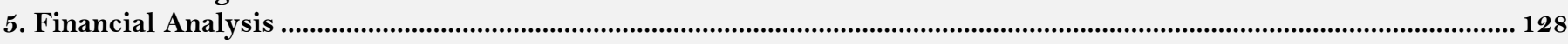

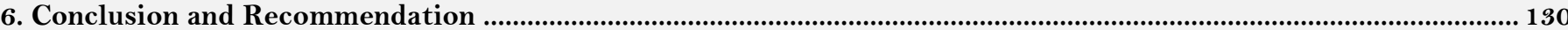

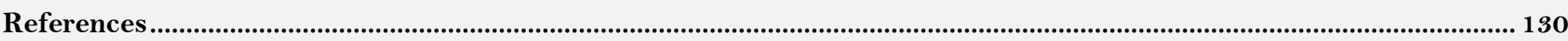




\section{Contribution of this paper to the literature}

This study contributes to the existing literatures by providing information on costs and return analysis associated with bread production including the resource use efficiency. This also makes data available for entrepreneur who is interested in bread production and related business in decicion making and planning.

\section{Introduction}

Bread is a staple fermented confectionery produced by baking dough recipes largely based on or containing significant quantities of wheat or other cereal flour which are blended with other ingredients [1]; [2]. The breadmaking process has undergone dramatic development over the ages, from traditional baking which involves bread production using wheat flour, yeast (Saccharomyces cerevisiae), salt, and water followed by a series of processes such as mixing, kneading, proofing, shaping and baking to commercial industrial production on a large-scale basis that involves the use of enzymes and additives to improve qualities of bread [3]. Several varieties of bread are available in Nigerian market wheat-meal bread, multigrain and kibbled bread, rye bread and fruit bread. The wheat-meal bread comprises whole wheat and white bread usually referred to as sandwich or sugar bread. The white bread is made with wheat flour from which the bran and germ layers have been removed [4].

The bread business in Nigeria is dominated by the white bread while the whole bread is sparingly demanded by people with health challenges. It constitutes one of the most important sources of nutrients such as carbohydrate, protein, fibre, vitamins and minerals in the diets of many people worldwide. The consumption of bread in Nigeria is on a steady increase because it is convenient and ready-to-eat food. The desire for more nutritious baked goods is creating a new form of products in the specialized baked goods market. Bread is the most staple bakery food eaten by both the low and high social classes in Nigeria. It is relatively cheap, affordable and easy to find in the streets. It is widely consumed across the country by almost all citizens, ethnics, and religious groups.

According to Ohimain [5]; Malomo, et al. [6]; Odedeji and Adeleke [7] the consumption of bread has increased considerably in Nigeria due to population increase and urbanization, and the changing preference for convenience foods. Nigerian population of 198 million and which is expected to be the third most populous country in the world by 2050 [8]. The country has an estimated national population growth rate of 5.7 per cent per annum and an average economic growth rate of 3.5 per cent per annum in the past five years. In 2016, the value growth of bread in Nigeria was put at 12 per cent while other baked products were 11 per cent [9].

It is evident that investment in bread business is increasing. However, the investors require certain eminent information that would assist in the business projection for profitability. Economic feasibility assessment of a proposed business involves a cost/ benefits analysis of the project, helping organizations determine the viability, cost, and benefits associated with the project before financial resources are allocated [10]. It also serves as an independent project assessment and enhances project credibility-helping decision-makers determine the positive economic benefits to the organization that the proposed project will provide. It takes into account both quantitative and qualitative factors for analysis of the value for money for a particular project or investment opportunity. Therefore, it is imperative to carry out such research before embarking on any business as entrepreneurs.

Aside from economic feasibility, financial planning is also very important to handle the different operations of the organization within the budget limits. It covers assessment of total capital requirements, sales and prices, break-even outputs, amount of sales required to attain profit in the business. It helps entrepreneurs to get an idea about how much money is required for handling a business project successfully. However, economic feasibility studies and financial planning for a particular business may vary based on certain factors such as geographical location, culture, religion and so on. This paper provided an economic feasibility study of bread production business in Gashua, Yobe State, Nigeria with emphasis on the costs and return associated with bread production including the resource use efficiency. This will make data available for an entrepreneur who is interested in bread production in Gashua and its environ.

\section{Description of Methodology and Data Collection}

Primary data was used for the study. Two out of three existing bakeries in Gashua were selected for preliminary information on bread business in Gashua. The information on the cost of production and other analysis was based on laboratory scale production at the Home Science and Management laboratory, Federal University Gashua. The bread considered was the family size bread of between $0.85 \mathrm{~kg} \pm 0.05$ dough before the baking process. The bread contains 25 slices in a loaf. The price of fixed assets and consumables were based on a market survey at Alaba International Market, Lagos and cost at arrival in Gashua.

\subsection{Potential for Bread and Bakery Business in Gashua}

Gashua is a town in Bade local government. Yobe, Nigeria located at $12.87^{0} \mathrm{~N}$ latitude and $11.04^{0} \mathrm{E}$ longitude. It is situated at elevation 339 meters above sea level with an area of $772 \mathrm{~km}^{2}$. The estimated Nigeria population is 198 million and Yobe State with 2,321,339 people out which 125, 817 people live in Gashua. Yobe State is regarded as one of the States with low consumption of bread with Zamfara State at the bottom [11]. However, the steady increase of the Nigeria population would automatically affect the population of Gashua as a whole which might have either increased arithmetically or geometrically.

The bread bakery landscape in Nigeria continues to be dominated by unpackaged/artisanal producers with a slight edge over the packaged/industrial baked bread. Artisanal producers continued to lead baked goods in 2013, 2014 , and 2015 accounting for 53\%, 52.2 \%, and 50.91\% respectively of total current value sales. Special bread consumption in Nigeria is about $5 \%$ and the figure was expected to rise to about $10.5 \%$ and $11.5 \%$ in 2014 and 2015 respectively. The change in the configuration of people in Gashua who are elite would increase demand for special/good bread. According to Omeh [12] 10 million of loaves of bread are consumed in Lagos every day, 3 million in Jigawa which are related to the population of the two states; approximately 16 million and 5 million respectively. It could be estimated that 2 million loaves are consumed daily in Yobe State with a population of approximately 3,173,200 million and 130,000 loaves consumed in Bade Local Government. 
Gashua has a good advantage of notable nearby cities such as Nguru, Hadejia, Potiskum, and Azare. Damaturu which is the state capital is about $188 \mathrm{~km}$ from Gashua town. Gashua has the market for commercial activities for farm produce and cattle. This population is part of the market strength of the proposal. There are notable Federal Government Agencies in Gashua such as Prison, Military Battalion just some few distance and Federal University Institution of learning and a State College of Education with a large population from different parts of the country. These categories of workers provide a ready market for the bakery products especially bread. Factors such as population size, population projections, demographic and socioeconomic characteristics of the population, income and existing competition would have a positive change on bread consumption in Gashua.

\section{The Project}

The bakery project is to be located in Gashua, Bade Local Government, Yobe State. It is a type of a cottage modern bread-shop with the capacity of producing 5 bags of $50 \mathrm{~kg}$ per day at the start and maximum production of 10 bags. Plant production increases as marketing mileage is achieved. Other confectioneries such as special niche bread (whole wheat bread, banana composite flour bread, cakes, pies, biscuits in the same processing line) shall also be produced.

The bakery is a profit-making venture to produce premium bread. It is anticipated that the project will start with 5 bags of flour which is $50 \%$ of the installed capacity in the first year of operation, increasing to $60 \%, 75 \%$, $85 \%$ and $90 \%$ in second, third, fourth, and fifth-year respectively.

\subsection{Profit Potential in Bread Making}

Information about the financial cost of production and returns from a modern bakery revealed that it costs about 160.00 to produce medium-size standard sliced family bread in Nigeria. The bakers sell at $\$ 230.00$ to suppliers at a gain of $\$ 70.00$ per bread. The suppliers sell the bread to retailers at $\$ 260.00$ and make a profit of $\$ 30.00$ per loaf while the retailers sell to the final consumer at the rate of $\$ 300.00$ per loaf. The market analyses have revealed that 60.00 - 70.00 is the average gain that could be made on a family size bread (a bread of 25 slices) by the producer per bread in the market distribution.

A typical standard bakery with good supply sales sell at least 20,000 loaves of sliced bread weekly on average and makes a profit of $1,400,000.00$ per week $\$ 70.00 \times 20,000)$. This translates that a full-blown bakery produces approximately 34 bags of flour per day excluding 1 day of the week. However, to attain maximum production there is a need for structured marketing strategies, needs enhancements in the areas of packaging and value addition to bakery products [13].

The most artisanal bakery sells directly to the retailers at less cost. The same family size bread sold that usually sold at $\$ 230.00$ by modern bakery can go for $\$ 200.00$ to retailers and the retailers sell it at the rate of ₹250.00 but a lower cost of production such as 140.00 per unit. The variation is based on the technology and quality of the bread. The estimated cost of running the bakery per week below is based on 20,000 loaves per week as shown below. Therefore, the financial and profits and returns on bakery is impressive and worthy of investing in it.

\section{Manufacturing Process of Bread}

The manufacturing process fits into the production process of any type of bread with adjustment on the processing operation. Other baked products passed through similar processing unit operations. Straight dough method was used for the bread production as described by Ijah, et al. [2] with some adjustment based on the laboratory scale production. The bread-making process is mainly based on 3 steps: dough formation, fermentation and baking. The first step in preparation for mixing is assembling and weighing the ingredients. Some ingredients require special preparation. The yeast, whether compressed or dry must be suspended in water according to the manufacturer's instructions. This is usually written on the packaging material. The Baking formula was $60.80 \%$ wheat flour, $21.90 \%$ water, $9.70 \%$ sugar, $3.70 \%$ skim milk powder, $1.22 \%$ salt, $4.87 \%$ fat, $3.7 \%$ preservative, 0.5 $\%$ improver, and $1.22 \%$ yeast. All ingredients are mixed in a Kenwood mixer (Model A 907D) for 10 min.

The purpose of mixing the dough is to distribute the yeast cells throughout the dough, distribute food for the yeast, and to form and develop the gluten. Gluten is formed when the two proteins of the flour, gliadin and glutenin come in contact with water. The time required to develop the gluten depends on the strength of the flour and the speed of the machine. The dough was fermented in bowls, covered with wet clean muslin cloth for $55 \mathrm{~min}$ at a warm temperature. To ensure alcoholic fermentation which is most desirable, a temperature range between $25.5-27.5{ }^{\circ} \mathrm{C}$ was maintained during the processing. The dough was punched, scaled to $0.9 \mathrm{~g}$ dough pieces, proofed in a proofing cabinet at $30^{\circ} \mathrm{C}$ for 90 min and $85 \%$ relative humidity, and baked at $250^{\circ} \mathrm{C}$ for 30 min. The intense baking heat dries out the part exposed to the air and causes a crust to form. The golden-brown colour of the crust is the result of chemical changes in the starch, sugar and milk known as a browning reaction (Maillard reaction) also known as caramelisation. The baked bread samples are then depanned, cooled at ambient temperature and packaged in a polyethene bag.

\subsection{Functions of the Ingredients}

- Flour- Provides most of the bulk of the baked item. The wheat flour is high in gluten (protein) as this substance gives bread its fine texture and supports the ingredients during rising. Flour from another source can also be used as a substitute such as cassava flour, dry mushroom flour etc.

- Yeast: This is a microorganism that feeds on starch and sugar releasing $\mathrm{CO}_{2}$, alcohol and water. The $\mathrm{CO}_{2}$ bubble gives the dough light and airy texture.

- Fat gives a softer texture and helps prevent the $\mathrm{CO}_{2}$ bubbles from escaping from the mixture too soon.

- Sugar: provides a direct food source for the yeast improving its action.

- Vitamin C: Shortens the time for the dough to mature. 
- Egg: act as a binder and beaten egg white, like fat, helps to retain gas bubbles.

- Baking powder: This comprises of baking soda with acid added. It neutralizes the basic condition by producing $\mathrm{CO}_{2}$ according to the following equation:

$\mathrm{NaHCO}_{3}+\mathrm{H}^{+} \rightarrow \mathrm{Na}^{+}+\mathrm{H}_{2} \mathrm{O}+\mathrm{CO}_{2}$

The cost of production of bread using 5 bags of flour is provided in Table 1. The cost of materials was based on market price of the consumables at Gashua, Yobe State.

Table-1. Cost of production of 5 bags of flour per day.

\begin{tabular}{|c|c|c|c|}
\hline Materials & Weight (kg) & Price ( $)$ & $\begin{array}{c}\text { Price ( for } 5 \\
\text { bag/labour }\end{array}$ \\
\hline Flour & 5 (Goldenpenny) & $10,500.00$ & $52,500.00$ \\
\hline Sugar & 4.0 (Golden penny) ( $14,00.00$ for $50 \mathrm{~kg}$ ) & $1,120.00$ & $5,600.00$ \\
\hline Yeast & 0.20 (Royal) ( $1,500.00$ for $500 g)$ & 600.00 & $3,000.00$ \\
\hline Shortening & 2.00 (Crisco) ( $1,000.00$ for $1 \mathrm{~kg})$ & $2,000.00$ & $10,000.00$ \\
\hline Salt & $0.50\left(\AA_{200.00 \text { for } 1 \mathrm{~kg})}\right.$ & 100.00 & 500.00 \\
\hline Preservative & 0.20 (Probake CP) (\$23,000.00 for $25 \mathrm{~kg}$. & 184.00 & 920.00 \\
\hline Improver & $0.20(\$ 5,500.00$ for $1 \mathrm{~kg})$ & $1,100.00$ & $5,500.00$ \\
\hline Water & $25 \mathrm{~kg}$ & 100.00 & 500.00 \\
\hline Packaging Material & 1 pack of 100 units & 50.00 & 250.00 \\
\hline Total & & $21,618.00$ & $78,770.00$ \\
\hline Labour & I supervisor $(\mathrm{N} 30,000)$ and 2 attendants $(\mathrm{N} 40,000)$ & $70,000.00$ & $2,333.00$ \\
\hline Cost of fuel & Generator and Tricycle & $1,500.00$ & $1,500.00$ \\
\hline Cost of gas & Source of heat for baking & & $1,000.00$ \\
\hline Repair and maintenance & & & 300.00 \\
\hline Damages/depreciation & Damages/depreciation and other miscellaneous & & 600.00 \\
\hline Total Cost of Production & & & $83,903.00$ \\
\hline
\end{tabular}

\section{Financial Analysis}

5.1. Investment Capital

Investment cost of the bakery covers the acquisition of all capital items as reflected in the project cost below. Table 2 provides estimated project cost for the take off of the bakery. The cost of equipment are based on the landing cost in Gashua, Yobe State.

Table-2. Estimated project cost.

\begin{tabular}{|c|c|c|}
\hline & Specification & N \\
\hline Land and development & A plot of land $60 \times 120 \mathrm{ft}$ & $500,000.00$ \\
\hline Borehole water & & $500,000.00$ \\
\hline Building & Direct labour & $3,000,000.00$ \\
\hline Electric oven with gas & $\begin{array}{l}\text { This is an electric oven that can also use gas as source } \\
\text { heat with a capacity of baking } 50 \mathrm{~kg} \text { ( } 100 \text { standard } \\
\text { loaves of } 900 \mathrm{~g})\end{array}$ & $1,800,000.00$ \\
\hline Mixer & Spiral mixer with the capacity to mix 5okg at a time & $800,000.00$ \\
\hline Dough divider & & $250,000.00$ \\
\hline Dough moulder & & $800,000.00$ \\
\hline Bread slicer & Top table slicer & $250,000.00$ \\
\hline Measuring scale & & $100,000.00$ \\
\hline Working table & Stainless table $6 \times 3 \mathrm{~m}^{2}$ & $50,000.00$ \\
\hline Bread shelf/rack & Stainless steel & $20,000.00$ \\
\hline Gen. set (11 KVA) & Lister generator may also be used & $500,000.00$ \\
\hline Auxiliary office Equipment/furniture & & $100,000.00$ \\
\hline One Tricycle & Tricycle with extended housing & $700,000.00$ \\
\hline Laboratory equipment and reagents & & $100,000.00$ \\
\hline \multirow[t]{2}{*}{ Product registration with NAFDAC } & & $150,000.00$ \\
\hline & Sub -total & $9,620,000.00$ \\
\hline Add contingency ( $2 \%$ of total cost) & & $192,400.00$ \\
\hline Add manpower maintenance & Salary/wages for 6 months & $420,000.00$ \\
\hline Add initial working capital & & $83,903.00$ \\
\hline Total project cost & Total & $10,316,303.00$ \\
\hline
\end{tabular}

\subsubsection{Contingency}

The contingency provision of $192,400.00$ was made for items, not yet acquired. This is about $2 \%$ of the investment cost.

\subsubsection{Financial Plan}

The total project cost at $10,316,303.00$

\subsection{Financial Analysis for Five Years of Operation for the Proposed Bakery in Gashua}

The mixer and oven which are the major equipment can mix/prepare $50 \mathrm{~kg}$ of flour ( $1 \mathrm{bag})$ and baked the same quantity respectively in 1 (one) hour.

The cost of bread is related to quality and quantity. Mathematically, a bag (50 kg) of flour will produce 99 loaves of approximately $800 \mathrm{~g}$ of medium size bread. Such a loaf is sold at a market price of 300.00 . Half of such 
loaf goes for 200.00 . The bakery at inception shall focus on the production of standard size of $800 \mathrm{~g}$ sold at $\$ 300.00$ (market price) and 400g loaf sold at a market price of 200.00 .

The estimated cost of producing standard bread sold at $\$ 300.00$ is 170.00 and distributed to retailers at the rate of $\$ 20.00$ per loaf who is expected to make a profit of $\$ 50.00$ per loaf. The small loaf is half of the standard bread at 180.00 per loaf with 100.00 cost of production. The retailers receive the loaves at 140.00 per loaf.

The bakery is projected to start with 5 bags of $50 \mathrm{~kg}$ flour. An average of 40.00 gain is made from a loaf of $\$ 180.00$ and $\$ 80.00$ from the loaf of $\$ 300.00$. There is no significant variation in profits. Since two small loaves are almost equal to a big loaf, therefore, production of a standard (big) loaf is used for the financial analysis.

\subsection{Non-Current Assets Schedule}

The lifespan and annual depreciation of assets of the bakery is projected in Table 3.

\begin{tabular}{c|c|c|c|c}
\multicolumn{5}{c}{ Table-3. Non-current assets schedule. } \\
\hline & ITEM & Cost & Lifespan & Annual Depreciation \\
\hline & Building & Years & ( \\
\hline 1 & Factory building & $3,000,000.00$ & 25 & $120,000.00$ \\
\hline 1.1 & Plant and Machinery & & & \\
\hline 2 & Mixer & 800,000 & 10 & $180,000.00$ \\
\hline 2.1 & Rotary oven & $1,800,000$ & 10 & $25,000.00$ \\
\hline 2.2 & Dough divider & 250,000 & 10 & $25,000.00$ \\
\hline 2.3 & Dough moulder & 250,000 & 10 & $25,000.00$ \\
\hline 2.4 & Bread slicer & 250,000 & 10 & $50,000.00$ \\
\hline 2.5 & Gen. Set & 500,000 & 5 & $10,000.00$ \\
\hline 2.6 & Measuring scale & 100,000 & 10 & $20,000.00$ \\
\hline 2.7 & Utilities & & & $20,000.00$ \\
\hline 3 & Lab. Chemicals & $100,000.00$ & 5 & $100,000.00$ \\
\hline 3.1 & Furniture and fittings & $100,000.00$ & 5 & $655,000.00$ \\
\hline 3.2 & Tricycle & $700,000.00$ & 7 & \\
\hline 3.3 & Total & $7,850,000.00$ & & \\
\hline 4 & & & & \\
\hline
\end{tabular}

Table-4. Cash flow analysis.

\begin{tabular}{l|l|c|c|c}
\hline \multicolumn{2}{l}{ Bread Project Investment Appraisal } \\
\hline Year & Description & Cashflow & DF @15\% & PV \\
\hline & & $(10,232,400)$ & 1.0000 & $(10,232,400.00)$ \\
\hline 0 & Equipment & $(83,903)$ & 1.0000 & $(83,903.00)$ \\
\hline 0 & Working Capital & $8,709,560$ & 0.8696 & $7,573,530.43$ \\
\hline 1 & Cash profit & $10,612,232$ & 0.7561 & $8,024,372.02$ \\
\hline 2 & Cash profit & $13,466,240$ & 0.6575 & $8,854,271.39$ \\
\hline 3 & Cash profit & $15,368,912$ & 0.5718 & $8,787,225.32$ \\
\hline 4 & Cash profit & $16,320,248$ & 0.4972 & $8,114,047.62$ \\
\hline 5 & Cash profit & 83,903 & 0.4972 & $41,714.62$ \\
\hline 5 & Recovery of working capital & & & $31,078,858.40$ \\
\hline
\end{tabular}

Table-5. Income projection cost-volume.

\begin{tabular}{l|c|c|c|c|c}
\hline Statement of Income Projection Cost-Volume Analysis for Bread Production for 5 Years \\
\hline & Year $\mathbf{1}$ & Year $\mathbf{2}$ & Year 3 & Yea 4 & Year 5 \\
\hline Production capacity & $50 \%$ & $60 \%$ & $75 \%$ & $85 \%$ & $90 \%$ \\
\hline Units of Loaves & 180,675 & 216,810 & 271,013 & 307,148 & 325,215 \\
\hline Sales price/Unit (N) & 230 & 230 & 230 & 230 & 230 \\
\hline Total Revenue & & & & & \\
\hline COGP: & $41,555,250$ & $49,866,300$ & $62,332,875$ & $70,643,925$ & $74,799,450$ \\
\hline Material expense & & & & & \\
\hline Labour cost & $29,663,550$ & $35,596,260$ & $44,495,325$ & $50,428,035$ & $53,394,390$ \\
\hline & 840,000 & 840,000 & 840,000 & 840,000 & 840,000 \\
\hline Gross profit & $30,503,550$ & $36,436,260$ & $45,335,325$ & $51,268,035$ & $54,234,390$ \\
\hline Expenses: & $11,051,700$ & $13,430,040$ & $16,997,550$ & $19,375,890$ & $20,565,060$ \\
\hline Repairs and maintenance & & & & & \\
\hline Miscellaneous & 109,500 & 109,500 & 109,500 & 109,500 & 109,500 \\
\hline Depreciation & 219,000 & 219,000 & 219,000 & 219,000 & 219,000 \\
\hline & 655,000 & 655,000 & 655,000 & 655,000 & 655,000 \\
\hline PBT & 983,500 & 983,500 & 983,500 & 983,500 & 983,500 \\
\hline Tax @ 20\% & $10,068,200$ & $12,446,540$ & $16,014,050$ & $18,392,390$ & $19,581,560$ \\
\hline Net profit & $2,013,640$ & $2,489,308$ & $3,202,810$ & $3,678,478$ & $3,916,312$ \\
\hline Cashflow & $8,054,560$ & $9,957,232$ & $12,811,240$ & $14,713,912$ & $15,665,248$ \\
\hline Variable Cost (VC) & $8,709,560$ & $10,612,232$ & $13,466,240$ & $15,368,912$ & $16,320,248$ \\
\hline Fixed Cost & $29,663,550$ & $35,596,260$ & $44,495,325$ & $50,428,035$ & $53,394,390$ \\
\hline VC/Unit & $1,823,500$ & $1,823,500$ & $1,823,500$ & $1,823,500$ & $1,823,500$ \\
\hline Break-Even Point & 164 & 164 & 164 & 164 & 164 \\
\hline & 27,705 & 27,705 & 27,705 & 27,705 & 27,705 \\
\hline
\end{tabular}


A project of this nature involves a huge sum of money and as such the management must ensure that it is consistent with the company's long-term plan and also ensure that that the project provides adequate investment returns. Because of the huge sum of money involved, it is advised that the project be evaluated before it is undertaken to determine its viability.

The evaluation of the project shows cash flow of $\$ 1,395,161$ and it is $\$ 1,078,858$ above the initial capital investment which is a viable project to undertake Table 4.

Also, from the statement of income and break-even analysis below Table 5 , it shows that the project has a good margin of safety. The project generates an estimated $\$ 8,054,560$ profit in its first year and $15,665,248$ in the $5^{\text {th }}$ year which will continue unless the project cannot produce up to 27,705 loaves in a year which is the break-even units.

\section{Conclusion and Recommendation}

The feasibility and the economic-financial analysis revealed that bakery business could be successful in Gashua, Yobe State. The profit is considerable and is worth investing on. Increase in production will also translate into a high-profit base on demand. The bakery will also meet the goal by setting the standard in bakery business especially in producing safe bread and providing job opportunities. Any investment put into the project will be a worthy investment that will yield much return. It is, therefore, hitherto recommended for funding.

\section{References}

[1] O. O. Adekoyeni, A. F. Adegoke, and A. E. Ayano, "Nutritional, functional, sensory and microbial qualities of wheat-tomato seed flour bread," Carpathian Journal of Food Science and Technology, vol. 10, pp. 47-56, 2018.

[2] U. J. J. Ijah, H. S. Auta, M. O. Aduloju, and S. A. Aransiola, "Microbiological, Nutritional, and sensory quality of bread produced from wheat and potato flour blends," International Journal of Food Science, pp. 1-6, 2014. Available at: https://doi.org/10.1155/2014/671701.

[3] A. T. Yahaya, T. R. Shittu, M. A. K. Ogunjobi, C. O. Jayeola, and A. O. Williams, "Gross margin analysis of COCOA bread production," International Journal of Horticulture, Agriculture and Food Science, vol. 1, pp. 18-21, 2017.

[4] C. Guthrie, "The different types of bread from around the world. Retrieved from https://www.oola.com/day-to-daylife/2493632/what-to-watch-on-tv/," 2018.

[5] E. I. Ohimain, "The prospects and challenges of composite flour for bread production in Nigeria," Global Journal of Human-Social Science, vol. 14, pp. 1-11, 2014.

[6] S. Malomo, A. Eleyinmi, and J. Fashakin, "Chemical composition, rheological properties and bread making potentials of composite flours from breadfruit, breadnut and wheat," African Journal of Food Science, vol. 5, pp. 400-410, 2011.

[7] J. Odedeji and R. Adeleke, "Pasting characteristics of wheat and sweet potato flour blends," Pakistan Journal of Nutrition, vol. 9, pp. 555-557, 2010. Available at: https://doi.org/10.3923/pjn.2010.555.557.

[8] G. I. Agbara, A. Bade, S. H. Ali, and A. M. Fannah, "Evaluation of production, consumption and nutritive value of gurasa, an indigenous flat bread of North-Western Nigeria," International Journal of Scientific Research and Management, vol. 6, pp. 1-7, 2018. Available at: https://doi.org/10.18535/ijsrm/v6i5.fto 1.

[9] Statista, "Nigerian baked goods and bread value growth 2016 statista research department. Retrieved from. Statista Research Department. https://www.statista.com/statistics/856356/nigeria-baked-goods-and-bread-value-growth," 2016.

[10] A. Saeed, "Economic feasibility study: Preparation and analysis, Sultan Qaboos-Academic publication and outreach department," Sultnate of Oma, pp. 1-7, 2019.

[11] Nigeria Bureau of Statistics, "Consumption pattern of bread in Nigeria. Nigeria data portal Retrieved from https://nigeria.opendataforafrica.org/yzqsxpd/consumption-pattern?tsId=1000090 " 2014 .

[12] D. Omeh, "Food processing-manufacturing: How to start a bread bakery business in Nigeria. Retrieved from https://www.wealthresult.com/food-processing/how-start-bread-bakery-business," 2019.

[13] S. Kiumarsi, K. Jayaraman, M. I. Salmi, and V. Asra, "Marketing strategies to improve the sales of bakery products of smallmedium enterprise (SMEs) in Malaysia," International Food Research Journal, vol. 21, pp. 2101-2 107, 2014. 